\title{
(Post)Colonial Pipes
}

Urban Water Supply in Colonial and Contemporary Jakarta

\author{
Michelle Kooy and Karen Bakker ${ }^{1}$
}

\section{Introduction}

Like many megacities in the South, Jakarta's water supply system is highly fragmented. The formal water supply system reaches less than $5^{\circ}$ per cent of the city's inhabitants; extending to mostly higher income areas of the city, the spatial distribution of the piped water supply system recalls a scattered archipelago rather than a homogeneous network (Bakker 2003). The majority of Jakarta's residents make use of a variety of highly differentiated sources bottled water, vendor water, shallow and deep wells, public hydrants, network connections - to meet their daily water needs (Kooy 2008), often relying exclusively on water provided, managed, delivered outside of the network (Bakker et al. 2008; McGranahan et al. 2001; Surjadi et al. 1994). Indeed, a significant proportion of households with connections to the networked water supply system continue to rely primarily upon other sources of water supply given low water quality and low network pressure.

This fragmentation of access to water supply and sanitation has been characterized as one of the key development challenges for the South in the next century. Halving by 2015 the proportion of people without sustainable access to safe drinking water and basic sanitation is one of the Millennium Development Goals established by the international community at the World Summit on Sustainable Development in Johannesburg (2002). The World Health Organization estimates that 1.1 billion people worldwide do not have access to safe drinking water, and 2.4 billion are without access to adequate sanitation (WHO 2004). An increasing proportion of users without access to adequate water supplies live in urban areas; despite residing in a metropolitan

1 Research assistance from Ernst Jan Martijn and Nur Endah Shofiani is gratefully acknowledged, as is the role played by host Professor Teti Argo at Institut Teknologi Bandung during research visits to Indonesia. The usual disclaimers apply. The research upon which this paper is based was funded by a grant from the Social Sciences and Humanities Research Council of Canada. Assistance from water supply managers at PAM Jaya and staff at numerous government departments and NGO offices during fieldwork conducted in Jakarta in 2001, 2004, and 2005 is gratefully acknowledged. Assistance from archival staff at the Koninklijk Instituut voor de Tropen (Amsterdam) and Koninklijk Instituut voor Taal-, Land- en Volkenkunde (Leiden) during research in 2003 is also gratefully acknowledged.

(C) MICHELLE KOOY AND KAREN BAKKER, 2015 | DOI 10.1163/9789004280724_004

This is an open access chapter distributed under the terms of the Creative Commons Attribution-

Noncommercial 3.0 Unported (CC-BY-NC 3.0) License. 
area, poor families in large cities in the South frequently do not have networked water supply access.

Various authors have explored why this fragmentation has emerged, and attempted to explain why it has proved to be so generalized and persistent in cities in the South (see, for example, Balbo 1993; Graham and Marvin 2001; King 1990). However, many of these analyses are predicated on the assumption of a modern infrastructural ideal of universalized, homogeneous provision of networked utility services; their central concern is with the 'fragmentation' which these supposedly universal networks are experiencing. In addition to presuming the existence of this universal network, most of the analyses applied to interpret the conditions of water access in Jakarta also presume the goal of universal access through a centralized networked system (Graham and Marvin 2001).

In contrast, this chapter chronicles the historical construction of Jakarta's urban water supply system to illustrate how the city's water supply has always been fragmented. Our analysis of the absence of an urban infrastructural ideal in Jakarta explains the persistent fragmentation of access in Jakarta as the product of (contested and contradictory) colonial and postcolonial government. We assert that the flows of water in the contemporary city of Jakarta must be understood as a historical product, both of colonial infrastructure and discourses. We are wary of any simplistic comparisons between the colonial past and present, but - in agreement with other scholars (for example, Myers 2006) - we believe that a postcolonial optic is necessary to unlock crucial elements of colonial legacies. Specifically, we argue that the optic of postcolonialism provides the understanding required for dissecting the power relations which continue to structure access to water supply and urban space in Jakarta, a dynamic which complicates Northern-rooted narratives of urban infrastructure, and also the developmentalist narratives of international aid and multilateral financial organizations.

We employ a framework of (post)colonial governmentality to explore the interrelationships between urban governance and infrastructure in Jakarta. This analytical framework is operationalized to understand how power operated through discourse and material practice to shape access to water supply in Jakarta, from 1920-1960. Documenting how relations of power were materialized and contested via hydraulic networks through the project of colonial government in the early twentieth century, and through later attempts of postcolonial governments to modernize selected spaces in the city through the provision of large-scale water supply projects. The case study that follows uses this framework to demonstrate how (post)colonial relations of rule both shaped, and were shaped by the material and discursive 
differentiation of water supply networks, urban spaces, and urban residents in Jakarta.

\section{Colonial Control: Governing Urban Water, Urban Populations, Urban Spaces}

The history of Batavia's urban water infrastructure begins with the rise of the sanitary city in the nineteenth century, in which a new discourse around water, identity, and citizenship emerged and was articulated to a new system of colonial authority. In the following chronology of the development of a modern urban water supply in colonial Batavia we begin with the construction of the artesian and piped spring water infrastructure prior to the 1920s. This is necessary, as it illustrates how the construction of the city's water supply infrastructure was, from inception, intersected with constructions of the civilized and modern colonial subject. Governing water in the colonial period, implied and enabled new categorizations and divisions: most importantly, the delineation of the public into different categories of populations (European versus mixed races versus native; hygienic versus contaminated), which guided the pattern of provision of these first urban water supply systems.

By the end of the 1920s, after five decades of development of the city's water supply system, only 7 per cent of the European colonial residents consumed $7^{8}$ per cent of the city's piped water supply. ${ }^{2}$ This is explained by the conflicting ethical mandate of the colonial government in the last years of colonialism: the mandate to uplift versus desire to dominate; the project to modernize but yet retain distinctions and hierarchical relations between authority and subject. These conflicting mandates explain why the construction of the first centralized water supply system intended for eventual universal coverage facilitated new fragmentations of populations and urban spaces.

\section{Artesian Water Supply (1870-1920)}

The problematic of urban waters and the unhealthy city plagued the colonial town of Batavia from its founding in 1619. High rates of mortality in the 1700 s that demoted Batavia from the Queen to the Graveyard of the East were attributable to water borne disease (Abeyasekere 1987); however, prior to the nineteenth century there were no direct links made between the health of body

2 In 1929, 6,926 kampong households were supplied with $24 \mathrm{~L} / \mathrm{s}$, while 10,392 European households were supplied with $84 \mathrm{~L} / \mathrm{s}$. The European population in Batavia in 1930 was 37,067, while the native Indonesian population was over 400,000 (Eggink 1930). 
and consumption of a standardized quality of clean water, and concerns regarding the health of the city and its citizens focused more generally on the urban environment's 'killing vapours', and miasmas (Blussé 1985). Flight from the contaminated spaces and surrounding populations characterized by death and disease was the only solution, and European residents repeatedly tried to escape the ziektenhaard (breeding ground for disease) by continually moving southwards away from the northern old city.

It was not until the mid-18oos that connections began to be made between healthy urban spaces, populations, and water supply, motivating the first significant governmental intervention into the production of a hygienic water supply, enrolling the governance of a new urban water supply within the government of a newly emergent city and its citizens, and marking the beginning of our genealogy.

In 1873 the central government, represented by the Raad van Indië (Council of the Indies) in Batavia, concluded a decade of commissions investigating the problem of water supply for Batavia by financing the construction of a series of artesian wells. From 1873-1876 seven wells were drilled, with all costs covered by the central government (Maronier 1929), and the architecturally elaborate communal hydrants located in the central areas of the city provided - free of charge - an emerging new class of European population with a secure, scientifically monitored water supply. ${ }^{3}$ The production capacity of the artesian water supply system increased along with the influx of an entrepreneurial European population who brought with them domestic habits and habitats from the metropole. ${ }^{4}$ In 1920 at the end of the era of artesian water, there were 28 wells and 12 reservoirs with a capacity of $750 \mathrm{~m}^{3}$, providing an increasingly clustered European urban population with a modern water supply through individual house connections (Maronier 1929).

The new mentality of colonial government which arose in the late 1800 s was central to the ways in which Batavia's water supply was first problematized, and then addressed through interventions constructed as rational solutions. When the artesian water supply began construction in 1870 , the management of the colony shifted from the Cultuurstelsel (Cultivation System) monopoly, a form of colonially administered market capitalism (Robison 1986). The purpose of colonial government subsequently altered from being an estate

3 In the last quarter of the nineteenth century the resident, 'mixed blood' or Indische population and their characteristic lifestyle was gradually eliminated in favour of a more rigid, racialized European population and domestic milieu (Milone 1967; Taylor 1983).

4 Between 1890-1920 the number of European men in the colony doubled, while the number of European women increased by almost 300\% (Locher-Scholten 1997; Van Doorne 1983). 
manager of a vast government plantation to that of facilitator of private sector participation. The provision of public infrastructure to facilitate private sector profits (providing the conditions for capital) thus justified the modernization of urban infrastructure, ${ }^{5}$ and inaugurated unprecedented government-led initiatives to combat public health issues threatening the image of the colony as a place for private sector investment (Argo 1999). The project of creating a modern city with all of the attendant infrastructure to support the influx of European bodies and European capital was begun, setting in motion a process that would change the urban landscape and the relationship between urban populations (see Milone 1967).

Paralleling the government's new strategy for ensuring the colony's economic security was a new level of concern for the health of particular kinds of colonial populations. Prompted by a scientific understanding of water introduced by recent application of microscopes and the study of bacteria, new connections made between water supply and human health began to rationalize government investments and initiated the development of new discourses around 'safe' water supply sources and water use practices. With the advent of new scientific technologies, the definition of water - its properties and potentials - became standardized, with the methodologies of analysis and scientific properties of water circulating through the professional journals of Europe. In the Netherlands Indies, an increasing uniformity of taste and understandings of quality was fostered by analyses of drinking water quality by military doctors (Moens 1873). Amongst the colonizers, previous appreciations for the distinct qualities of different waters (with specific properties of water linked to treatment of specific ailments, or religious rituals, see Hamlin 200o) were to be replaced by a more unified understanding of water as defined by a scientific analysis of its biophysical properties, since it was

questionable whether there has been enough care [by the European population] to purify the water [...] concern for hygienic water supply is often remarkably neglected by otherwise very civilized people and the inherent danger is very little respected.

MOENS 1873:311

The shift from recognizing many waters of various beneficial properties, to only one scientifically defined nature for water with its quality determined

5 From the 1870-189os, the construction of railways, harbours, steam-powered trams for intracity transport, and electricity networks paralleled the construction of the city's water supply network (see Mrázek 2002). 
negatively (in other words, by what it did not contain) precipitated the development of centralized systems of water supply throughout the world (see Melosi 2000). Within the Netherlands Indies this new understanding of water also circulated a new discourse around modern identities and development that re-rationalized colonial authority upon the basis of technological mastery and increasingly racialized the previous class based divisions between urban spaces and urban populations (see Milone 1967). In other words, the colonial authority which imposed European domination upon an indigenous population was now constructed as legitimate because of its advanced technical and scientific knowledge about the relationship between water and health. As is further documented in the following paragraphs, the use of clean versus unclean water sources by European colonial residents in comparison with indigenous residents was seen to demonstrate the rationality of colonialism, and naturalize racial divisions.

With the influx of a new kind of European population leading the wave of private sector penetration of the colony (Gouda 1995), the development of increasingly homogeneous, modern, and distinctly European settlements were to be provided with a modern, hygienic water supply. As 'science was giving completely different insights concerning hygienic requirements' (Maronier 1929:230), traditional water supply sources (surface water) were now rejected as contaminated, necessitating their replacement by a centralized, controlled, and scientifically monitored artesian water network. Facilitating the emerging concentration, and isolation of new European neighbourhoods within the city centre (see Abeyasekere 1989), the new class of European colonials became increasingly removed - both physically, and temporally - from the unhygienic native populations who remained 'in the past', still crowded alongside the traditional surface water sources that they continued to rely on for all of their water needs (Argo 1999).

The connections established between knowledge of the scientific properties of water supply and an individual's status as developed underpinned the construction of a new hierarchy of waters, and of water users. The continued use, and preference, of untreated surface water by native populations for drinking, bathing, and washing served to reinforce in a variety of ways the superiority and advanced knowledge of the purified and modernized European population and led to the production of a discourse linking undeveloped native bodies with surface water, disease, and contamination. The fact that 'natives take pleasure bathing, washing, and defecating in streaming water [demonstrated] their insensitivity to cleanliness and order' (Van Leeuwen 1920:198), and the recorded distaste of the native population for artesian water (Van Breen 1916) - a water supply that required a time consuming 
and expensive process of aeration and cooling before consumption - seemed to affirm their evident lack of modernity, and their status of non-citizens within a modernizing urban landscape. Remaining reliant upon the traditional and unscientific properties of water (colour, clarity, taste, smell) to determine its quality, native water users were 'not yet modern', and actively excluded from membership within the public that the artesian water supply was built to serve.

The division of urban spaces and populations according to their racialized level of modernity and development was incorporated into the water supply infrastructure of the late nineteenth century. Intended to help define what was then a rather racially ambiguous European population (Stoler 1997), the artesian water supply provided a hygienic, safe water supply, and cleansed a problematic, heterogeneous European population that had begun to jeopardize the strategy of colonial domination based upon demonstrated racial superiority (Stoler 1997). By locating the artesian hydrants within the emerging concentrations of new kinds of European settlements, the provision of urban water supply was in line with the overall governmental strategy to both discursively and physically secure a more modern, more European, population. As subsequent phases of the development of the city's water supply network channelled even more modern waters through later pressurized piped networks, the fragmentation between different kinds of urban populations, urban space, and water supply continued to be guided by the physical and discursive artefacts of the artesian hydrants.

Throughout the first decade of the twentieth century, the increasing advancement of European water supply from non-piped provision to private household connections was made possible by the initial construction of the artesian water hydrants and reservoirs within European spaces of the city, and high reservoirs and piped networks providing a pressurized water supply to European households contrasted with the emerging development of the 'corporeal networks' of native water vendors serving the native population, a pattern of provision still evident in present day Jakarta (Figures 3.1 and 3.2).

\section{Hydraulic Modernity: The Development of the Spring Water Network} (1920-1945)

The second phase of colonial intervention into urban water supply emerged after the composition of a demonstrably different European class of citizen was secure (Milone 1967; Van Doorn 1983); then the colonial administration turned to the task of constructing a new kind of native population. Seeking to address the increasing anti-colonial critiques calling for a more ethical and humane government of the Netherlands Indies (Gouda 1995), the 1901 Ethical 


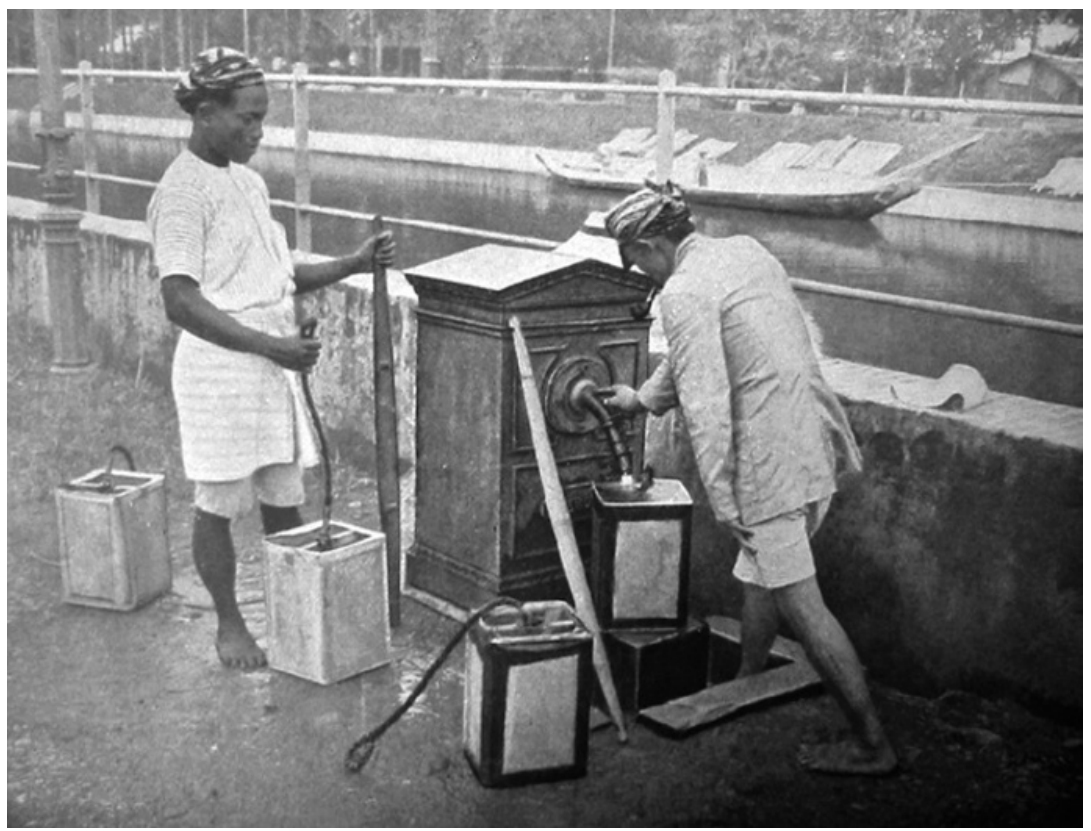

FIGURE 3.1 Water vendors in Batavia filling gas jerrycans with artesian water from a public hydrant (1918)

SOURCE: DROST (1918: PLATE OPPOSITE PAGE 54)

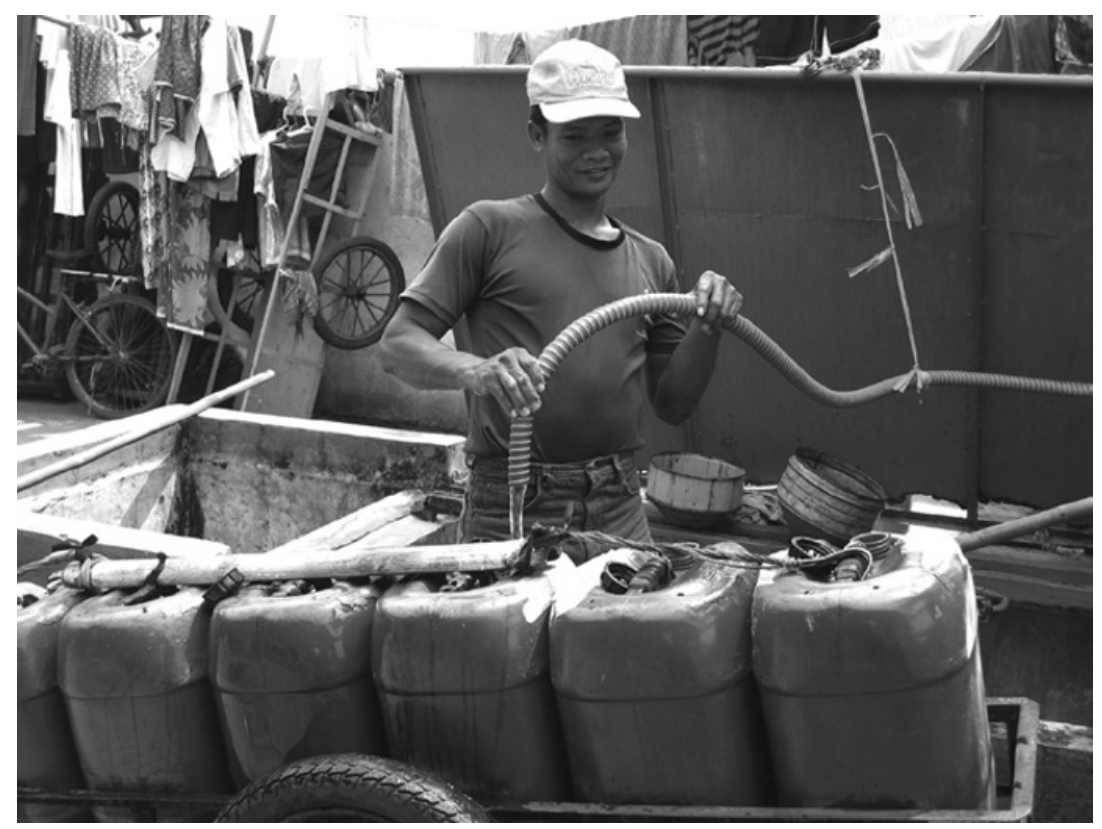

FIGURE 3.2 Water vendor in North Jakarta filling 'pikuls' of water from a public hydrant (2005) PHOTOGRAPH: M. KOOY 
Policy laid out intentions for new relations between the population and the state, partially materialized through the construction of a better quality and quantity of water supply that would increase the possibility of eventual universal distribution. Repositioning itself as a parental caretaker of the native population, the state was still authoritarian in nature, but now with the development of the native population into modern, self-productive citizens at the heart of its policies. The new priorities, purposes, and political strategies of government (both central government and the newly established municipal government of Batavia, in 1905) were embedded in the changing rationalities around urban water supply. Public health and economic efficiency (of water supply and of the population as a whole) became sometimes contradictory guiding principles determining decisions made about urban water: the selection of technology (high pressure versus low pressure networks; public hydrants versus household connections), water supply sources (spring water versus artesian water), and patterns of provision for different populations.

Although the transition between what was now described as an inadequate and antiquated artesian water supply system and a modern, centralized, high pressure, spring water supply stretched out over two decades, ${ }^{6}$ from 1900 to 1920, colonial chroniclers describe the technological shift as though it were a notable break with the past eras of water supply, indicating the significance invested in this material symbol of a new kind of government (Maronier 1929). With the transition to the spring water network, water production capacity increased to over $350 \mathrm{~L} / \mathrm{s}$, reservoir size grew from $780 \mathrm{~m}^{3}$ to $20,000 \mathrm{~m}^{3}$, the city network was extended by over 150 kilometres (Smitt 1922), and best of all - the water from the pipes could be used straight out of the tap without need for purification, or cooling, as was the case for artesian water. The planned provision of $90 \%$ of European households with a supply of $140 \mathrm{~L} /$ capita/day (Van Breen 1916) enabled a new kind of life,

imparting to the Batavia house a more European character [...] as most bathrooms have nowadays a shower from which the fresh water from the tap may be showered over the body.

GEMEENTE BATAVIA 1937:70

Based upon scientific knowledge developed in the West, for Western cities, demonstrating technological mastery over the health conditions thought

6 Investigations into rehabilitating and/or replacing the artesian water supply system began in 1906, following the Decentralization Act of 1903 that established Batavia as a municipality with its own local government. 
endemic to the tropics, and facilitating a modern urban lifestyle, the spring water network symbolized the emergence of a new kind of colonial government, a new kind of city, and a new kind of urban citizen.

The new colonial project of modernizing the native population, and the need to urbanize their traditional habits around water supply not considered conducive to the modern city supported both the construction of the spring water network and subsequent interventions of the colonial government into these problematic urban spaces. As articulated at the time, if it was 'the intention of the Municipality to keep the population out of the kali's [canals]', there would naturally have to be an alternative supply provided - a hygienic supply would have to be 'more easily placed under everyone's reach' (Van Raay 1915:142). Public health professionals in the Netherlands Indies believed that

the first requirement for improving kampong conditions is seen as the adequate supply of good drinking water [...] adequate supply is important because every necessary reduction [in supply for natives] can lead to the use of suspect water,

GOMPERTS 1916:11

and so previous plans for the spring water network only intending to supply to the European (profitable) areas of the city were revised, and the cost calculations increased from eight and a half to ten million guilders in order to extend the supply into kampongs (Van Leeuwen 1917). ${ }^{7}$

Identified as a crucial strategy for securing public health, and an important component of government's mandate to develop a modern, productive, and efficient native population, the spring water supply to native communities was at first provided free of charge from public hydrants (1922-1926). However, as the financial health of the newly established municipal water supply company (1918) became strained by the high costs of construction of the spring water pipeline, ${ }^{8}$ the efficiency of the native population was targeted for

7 Residents of the urban kampongs in the beginning of the twentieth century were not only native, but also included lower class European residents. Residential segregation between the planned European neighbourhoods and the urban kampongs were based on socioeconomic class as well as race, although scholars such as Stoler (1997) have noted the imbrications of class with race by the colonial government in its concern to uphold the moral superiority of the European population.

8 The spring water supply network eventually went between two to five million guilders over its original budget (Eggink 1930). The total cost of the spring water network system was 
improvement, and the payment for water supply was justified on the grounds that a new system of valuation around water supply would help to develop more economically efficient users. Water that was paid for would 'gain more value in the eyes of the [native] population so that it is no longer wasted in despicable ways' (Brandenburg 1924:153). When the municipality established a system of paid delivery in 1926, formally appointing existing native water vendors to sell water taken from the public hydrants at a determined profit margin (Eggink 1930), the introduction of new economic regulations around water supply through a system of 'paid kampong water delivery' were supposed to circulate a new understanding of water, and its economical value - a key aspect of a modern mentality - amongst the kampong population.

As the municipal distribution network was paid for by the city, and not the central government, this was important for the fiscally conservative municipal council who financed only two of the total nine million guilders needed to build the spring water network. The increasing costs to the municipality for its 'free water' supply budget as a result of increased use by native households was documented from 1920-1924; in 1920 the municipality spent only 54,000 guilders on 'free water', but by 1924, it paid out 120,850 guilders (Eggink 1930). However, after the regulation of 1926 charged a cost price of 60 cents $/ \mathrm{m}_{3}$, native residents returned to their traditional habits, resulting in a corresponding decrease in demand for network water supply in native areas (Maronier 1929). As recorded by colonial engineers, there was a dramatic reduction in the demand for networked water in the kampongs after the implementation of the paid water delivery system; by 1927 the budget for 'free of charge' water had dropped from 120,850 guilders to only 6,000; by 1930, 'concerning the free of charge water provision, so little is being expended that the amount of it is not expressed in the company's budget anymore' (Eggink 1930:63).

The use of hydrants and water vendors for kampong water supply was described as a merely transitional measure, an early stage in the development of universal water supply, because the willingness and ability to pay for direct connections of all kampong households was expected to follow from the adoption of sufficiently efficient and economically rational identities by the native population. The development of the native population into modern citizens whose health, economic productivity, efficiency, and aspirations led them into a higher socio-economic class would 'stimulate water use from

nine million guilders, with the municipality financing the costs of the city distribution network (two million guilders); the central government financed the fifty three kilometres of pipes which brought the spring water from Buitenzorg (Bogor) into the high reservoir at the edge of the city, almost seven million guilders (Maronier 1929). 
house connections' (Maronier 1929:236). At the same time, whoever was not motivated to maintain a sufficiently modern, economically rational, and hygienic lifestyle was subsequently displaced, as the necessity of recovering the costs of the expensive iron pipes that stretched 53 kilometres between the spring and the city meant that the occupation of these predominantly native urban spaces now modernized through the provision of piped water supply were only affordable to a certain class of urban resident. ${ }^{9}$ The provision of water supply services and other improvements to the kampong areas increased land values and house rents, and moved poorer families to the outskirts of the city boundaries, or to more undesirable unimproved kampongs (Van der Wetering 1939). The changing demographic composition of these improved areas into middle class housing areas (Abeyasekere 1989) was reflected in the decreasing number of hydrants, and increasing number of house connections within improved kampongs (see Maronier 1929). The poorer segment of the native population subsequently moved out from the modernized kampongs in the urban centre to the outskirts of the city, while those areas with piped water became populated by the new administrative middle class of salaried Indonesians, and Eurasians (Abeyasekere 1989; Van der Kroef 1954). As the 'silent battle for living space' (Van der Wetering 1939:315) continued to displace native communities for the building of new European residential districts and associated services (railways, tramways) (Wertheim 1956), the spatial separation of two increasingly distinct urban societies was also in part facilitated by the spring water network.

Reflecting the conflicts contained within colonial policy, the 'raising up' of a relatively small percentage of the Indonesian population entailed creating new divisions of urban populations, urban spaces, and access to services, along the new colonial hierarchy of modernization. Modern natives, with suitably economically rational and productive identities motivated to improve their socio-economic status occupied urban spaces provided with networked urban water, and the larger lower class of undeveloped Indonesians still reliant upon day labour and low paying wages remained in the un-serviced areas of the city, or moved outside of the municipal boundaries altogether (Van der Wetering 1939). Urban water supply also embodied other conflicts that became acute in the last years of the colonial government. The colonial project to modernize

9 With the cost of a connection to the network set at 25 guilders, monthly fees for meter rental (0.5-1.5 guilders) and the cost of the actual water being $0.30 \mathrm{cent} / \mathrm{m}^{3}$ (Jaarboek van Batavia 1927), networked water supply was well out of reach for the average native resident, when 'the largest category of the native city population can not pay a rent of five guilders/month' (Van der Wetering 1939:325). 
but yet retain distinctions and hierarchal relations between authority and subject explain why the construction of the first centralized water supply system intended for eventual universal coverage facilitated new fragmentations of populations and urban spaces.

With a design that planned for $140 \mathrm{~L} /$ day to be distributed to $90 \%$ of the European households in Batavia, in contrast to an expected delivery of only $65 \mathrm{~L} /$ capita/day to only $33 \%$ of the native population (Van Breen 1916), the European population consumed the vast majority of the water from the spring water network..$^{10}$ Provided with a convenient supply of water piped directly into the home, and delivered at a higher pressure than through hydrants, European households naturally (or, as expected and designed) came to use the majority of this water supply. With the worldwide depression in the 1930s, and the drop in colonial economy because of falling sugar prices, the campaigns of kampong improvement ended, along with the Ethical nature of colonial government policies (Cobban 1974, 1988; Coté 2003). ${ }^{11}$ By the time the colony's economy had recovered, and programmes of kampong improvement were resuscitated in 1938-1939, the Second World War had begun. Suffice it to say, up until the end of Dutch colonial occupation access to the city's public services remained limited to Europeans and a very small section of the native population whose living standards had improved. ${ }^{12}$

\section{Postcolonial Transformations: Urban Water for the Ideal Citizens of an Independent Nation, 1950s-1965}

The next significant moment in the history of the city's water supply infrastructure followed Indonesian Independence. Following the tumultuous and protracted transition to an independent Indonesian government (1945-1950) - the

10 In 1929 European households comprised only $7 \%$ of the population, but consumed $78 \%$ of residential urban water supply (see footnote 2 ).

11 From 1927-1931, 1.25 million guilders was spent on improving kampongs in cities throughout Java, with the central government paying $50 \%$ of the costs; after 1931 government funding stopped, only to be revived again in 1938 when 500,000 guilders/year was again allocated to be distributed amongst all urban areas in the colony (Cobban 1974, 1988).

12 Although income disparities amongst the native population grew during the last years of the colonial economy, there is no doubt that it was disparities between rather than within ethnic groups that continued to be the most obvious as income gaps even increased during the 1930s. In 1939 a European made 61 times the average Native wage, while a Chinese worker earned eight times the average Native wage (Booth 1988). 
events including Japanese invasion, the return of Dutch colonial government, and the subsequent War for Independence - the city's spring water supply system was all but destroyed (Fischer 1959; Van der Kroef 1954). With a rapid increase in urban population, ${ }^{13}$ and the capital city of Jakarta emerging as the centrepiece of the new nation of Indonesia, the postcolonial development of Jakarta's urban water supply system was quick to follow formal independence.

As in the previous eras of the artesian and spring water networks, the physical changes to the city's water supply system materialized the introduction of new relations of rule. With the construction of the first two large scale surface water treatment plants (Pejompongan I \& II) replacing pure mountain spring water with treated surface waters (enabling a much larger volume of production at lower cost), a new nature of urban water supply was produced to flow through the new citizens and spaces of the postcolonial city. Physically, the transition from colonial water supply technologies - to the postcolonial placed the priority on water quantity over quality, in order to provide a larger volume of water for the growing Indonesian population migrating to the capital city of Jakarta. However, the (post)colonial water supply priorities also discursively represented the rescuing of surface waters (and their users) from the past and their connotations with contamination by treating them through Western technologies, thus reinforcing the transformation of colonial Batavia into independent Jakarta. ${ }^{14}$ By 1957, Pejompongan I was operational, adding $2000 \mathrm{~L} / \mathrm{s}$ of treated river water to the network; Pejompongan II (completed in the mid1960s) later added another $1000 \mathrm{~L} / \mathrm{s}$ (PAM Jaya 1992a).

However, just as the new surface water supply continued to be distributed through the colonial piped network, the discourse embedded within previous layers of urban water infrastructure continued to guide postcolonial patterns of supply. Newly modernized surface water supply was still limited to a particular kind of urban population - the symbolically modern spaces and citizens of President Sukarno's Jakarta. ${ }^{15}$ In short, urban water supply in postcolonial Jakarta came to reinscribe colonial patterns of provision within the postcolonial city.

\footnotetext{
13 Population increased in Jakarta from 823,00o residents in 1948 , to 1.8 million in $195^{2}$ (Abeyasekere 1989).

14 The spring water source did continue to contribute a small portion of the city's water supply up until 1994; in 1957, after the completion of Pejompongan I the colonial spring water supply would have provided between $15-30 \%$ of the total production capacity (see PAM Jaya 1992a for details on water production capacity over the years).

15 See Leclerc (1993) for a discussion of the politics of Sukarno's production of urban space.
} 
At the outset, national government investment to increase the capacity of urban water supply by $3000 \mathrm{~L} / \mathrm{s}$ could have been envisioned as the first steps of a new nation towards the democratization of urban water. Following the damage to the colonial water infrastructure during the wartime period, the existing system was incapable of meeting water demands from the rapidly growing population of Jakarta (Hanna 1959). The production of a new source of water to increase the volume of supply could be interpreted as a first effort of a new kind of government to serve its newly emancipated citizens, reclaiming public water as the government began to reclaim key industries and land from the colonial owners and its corporations (see Robison 1986).

However, this was not the case; the postcolonial centralized water supply network was important for its symbolic significance within a modern Jakarta, rather than its ability to provide water to city residents. Just as the first postcolonial investments into the city's urban water supply reflected the rationality of the 'city beautiful movement' whereby President Sukarno envisioned national greatness to be expressed through the physical transformation of Jakarta (Geertz 1963; MacDonald 1995), the networked water supply remained limited to certain modernized areas of Sukarno's 'monumental' Jakarta. Although not often recognized as a material component of this political programme, the geographical location of the water treatment plants, and the spatialization of networked water supply that they enabled demonstrate their material and discursive functions in this new rationality of rule, and reveal the mechanism by which colonial patterns of supply were inscribed within the postcolonial city.

Viewing the spatial relations between the urban water infrastructures and the other monumental structures of the 'city beautiful' movement, the significance of the water supply infrastructure to the national government project of an internationally modern Jakarta becomes visible, in a way that its subterranean presence usually obscures. With the location of the water treatment plants within the centre of the representative modern spaces of Sukarno's Jakarta (Figure 3.3) the piped network mirrors the above ground highways and flyovers built to connect the modern elements of the city, and was neatly positioned by the government to channel the increased flows of water to follow the new flows of international traffic into modern areas of the city, simultaneously excluding the vast majority of un-modern spaces and populations from both spatial proximity to, and services from, the network. ${ }^{16}$ The significance of the

16 The construction of the Asian Games complex and adjacent inner-city thoroughfare involved the removal of 47,00o kampong residents, moving them out of the central areas of the city needed for these modernist monuments and relegating them to the periphery (Abeyasekere 1989), beyond the boundaries of the water network. After the construction 


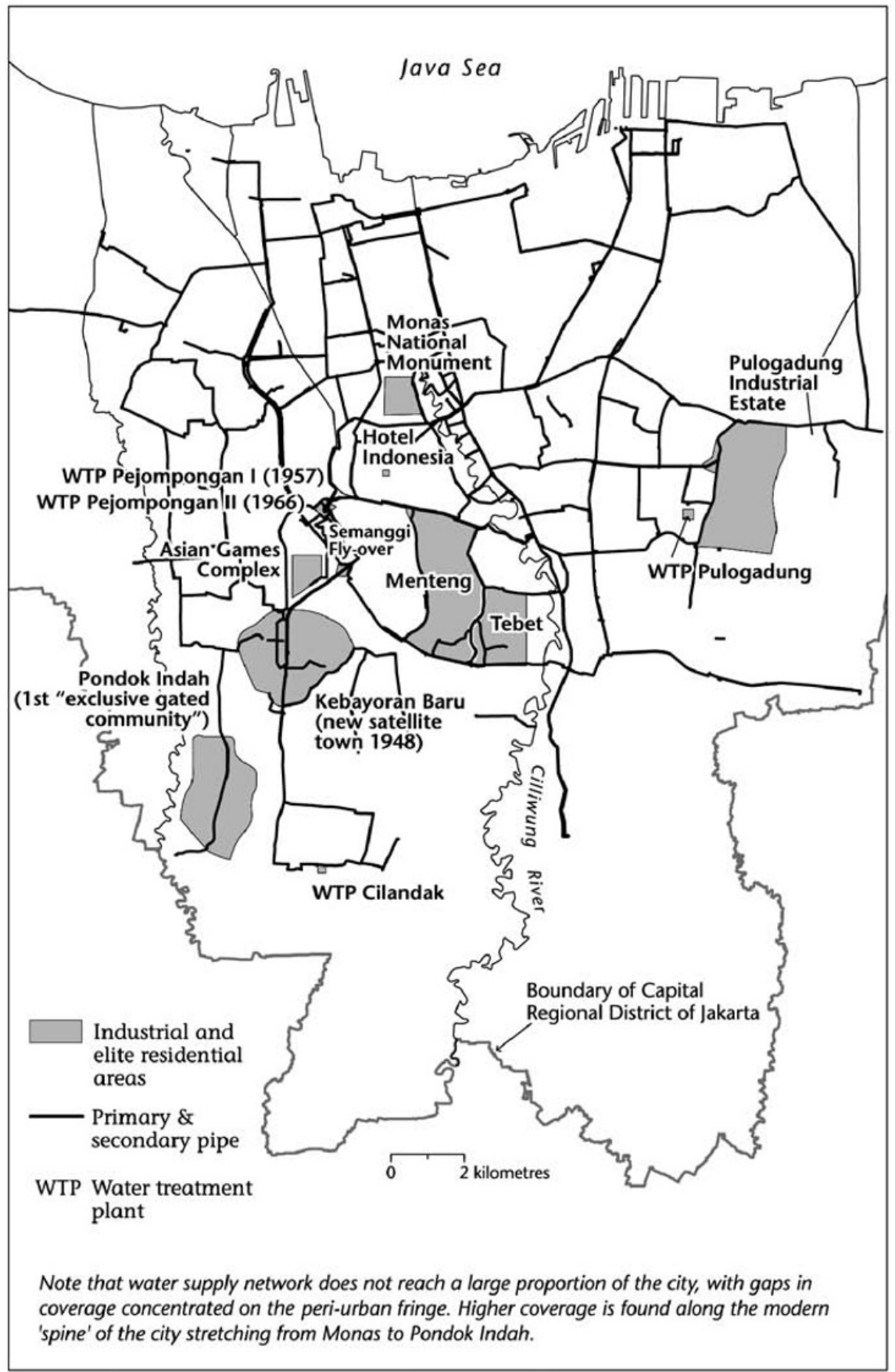

FIGURE 3.3 Reach of primary and secondary water pipes, $1950 \mathrm{~s}$ MAP DRAWN BY ERIC LEINBURGER 
new urban water infrastructure to the image of the nation was such that the central government provided all of the money for the construction of Pejompongan I, the argument given that Jakarta's water supply was part of the national project, not just for Jakartans (PAM Jaya 1992b). ${ }^{17}$

With people from all corners of Indonesia coming to Jakarta (PAM Jaya $1992 b)$, investments into a centralized water network serving the international centres of the city served the function of demonstrating a modern nation to the visitors; Jakarta was a 'modern city, with modern ways and urban conveniences' that (for some) drew the intended comparisons to other world cities, such as Paris (Van der Kroef 1954:157). Supporting the more frequently recognized components of Sukarno's Jakarta - the Asian Games complex, Indonesia's first international standard hotel (Hotel Indonesia), the high rise development along Jalan Thamrin-Sudirman, and the new upper class satellite city of Kebayoran Baru - the network water supply helped to brighten the beacon of Jakarta as it projected Indonesia upon the world stage.

The limited provision of piped water outside of this symbolically modern space in the centre of the city was therefore not a 'failure' of the government to invest in public infrastructure, but rather an integral part of a broader political strategy. As with the rest of the city's monuments that were planned to 'subsume the sober realities of life in Jakarta' (Kusno 1997), the investments of the first postcolonial government into Jakarta's urban water supply were intended to remind the nation (and Jakarta's residents) not of what they currently were, but what they (and the kinds of modern identities) they should aspire to. In the light of this nationalist discourse circulating through urban water supply, the fact that the majority of the urban population could not afford to connect to the network, or could not afford to use the water even if they were connected to the network (Fischer 1959) was not a failure of government to achieve the modern infrastructural ideal. Rather, postcolonial rule in the first decades after independence maintained the splintered nature of urban water supply through its rationality for the modernization of Jakarta.

Recognizing the Pejompongan I \& II water treatment plants as part of Sukarno's modernist monuments illuminates the ways in which colonial discourses around modernity, urban water, and citizenship were inscripted into postcolonial Jakarta, and rescues them from their obscurity in the history of

of Pejompongan I piped water was reported to be available to only $12 \%$ of Jakarta's population (Fischer 1959).

17 The central government later provided $50 \%$ of the costs of Pejompongan II, with the government of Jakarta responsible for the other half of the us $\$ 7$ million investment (PAM Jaya 1992b). 
Jakarta's public works. ${ }^{18}$ Excavating this first layer of postcolonial infrastructure also allows us to trace the continuing fragmentation of urban space through water supply, as the tripling of water supply in the central, internationally modern, areas of the city was both produced by and productive of postcolonial distinctions between modern/un-modern urban spaces and citizens. With the additional $3000 \mathrm{~L} / \mathrm{s}$ of postcolonial waters supporting the production of a 'new space intended to be different from both colonial Batavia as well as the surrounding sea of poor urban neighbourhoods' (Kusno 2000:52), the different natures of urban water circulating through selective areas in the city supported the government's intended differentiation between these areas of the postcolonial city. Divisions established between the kampong and the modern city were reinforced by the national government's consistent exclusion of kampongs from network access, leaving the majority of the non-modern residents to continue their historic (precolonial) reliance upon open wells and surface waters (Argo 1999).

In contrast to the kampong, where absence of piped water remained the norm, substantial investments were made to both rehabilitate and expand water supply into upper class residential areas of Jakarta. Recognizing certain kinds of residential areas of the city as part of the modern Jakarta (those that were planned, formal, and demonstrated rational spatial arrangements along orderly roads), the old colonial neighbourhoods in the central areas of the city were laid with postcolonial pipes, and new neighbourhoods constructed for the Indonesian elite in the south were immediately included within the modern strip of the city, connected both to each other, and to modern waters through the postcolonial network. Kebayoran Baru, the satellite town originally planned by Dutch post-war government in 1948, had already been fitted with $17 \mathrm{~km}$ of network pipes prior to postcolonial government, and pipelines from Pejompongan I were laid to channel its new waters into these modern urban dwellings now occupied by the Indonesian elite. In contrast, the migrants streaming into Jakarta during the 1950-196os settled in open spaces of the city, with an increasing density gradually creating 'vast block interiors

18 Pejompongan I \& II were each built at a cost of approximately $\$ 7$ million US (PAM Jaya $1992 b)$ but these significant investments are not addressed in either discussions of Sukarno's monumental Jakarta (see Kusno 2000; Leclerc 1993; MacDonald 1995), or the history of public infrastructure in Jakarta (see World Bank 1974; Hamer, Steer, and Williams 1986; Chifos and Suselo 200o). The familiar argument that Sukarno's government neglected public infrastructure in favour of public monuments ignores the construction of Pejompongan I \& II as both public infrastructure, and a monument for the modernization of the city. 
that became the sites of the un-serviced urban kampong' (Cowherd 2002: 173). In continuity with colonial patterns of provision, postcolonial urban water supply remained limited to modern areas of the city.

These patterns of provision remained the norm throughout the next three decades, as the subsequent New Order rationality of urban water supply both maintained and exacerbated the previous (post)colonial patterns of provision: layers of New Order infrastructure continued to benefit selectively targeted areas of the city, and the majority of the city's poorer residents continued to rely upon non-networked water supply, as the New Order's promise of development excluded these areas of the city (see Jellinek 1991; Kusno 2000).19 Public hydrants to provide access to clean water in kampongs, non-existent under President Sukarno, were still a rare occurrence in kampongs in the late 1970s (Argo 1999), and the few that did provide services repeated the discriminatory economic policy of the earlier colonial era. Until the mid-1980s public hydrants charged higher tariffs than those paid by the individual household connections to middle and upper income households, creating a perverse cross-subsidy from the poor to the middle and upper classes which persisted for the next two decades. ${ }^{20}$

\section{Conclusions: Flowing from Past to Present}

In documenting the genealogy of water supply in Jakarta, this chapter has argued that the city's water supply network has been highly 'splintered' (Graham and Marvin 2001) since its inception, and the roots of this highly fragmented pattern of water access lies in the colonial era. This spatial fragmentation of supply continued to be a pattern of growth inscripted into the postcolonial development of Jakarta's waters, and was therefore not substantially altered by the rise of the 'modern infrastructural ideal'. Documenting how a contested and evolving process of social differentiation of classes and races was linked to the differentiation of water supply infrastructures and of

19 In 1994, over $60 \%$ of the upper income population had direct access to network water supply through household connections, but only $10 \%$ of the kampong residents were directly connected (Azdan 2001; Cestti, Batia and Van der Berg 1994; Porter 1994; JICA 1997).

20 Until the early 1980 s, household tariffs were 25 rupiah per cubic metre for the first $15 \mathrm{~m}^{3}$ / month; public hydrants and water trucks paid 60 rupiah per cubic metre, more than double the tariff of households, and more than even small businesses, who paid 50 rupiah per cubic metre. Lower prices for hydrant water were only introduced in the mid-1990s (Kooy 2008). 
urban spaces, we traced the legacy of the colonial constructions of urban water supply and citizenship within the postcolonial city.

We began our story at the moment of the first major colonial intervention into urban water supply - the construction of a system of artesian wells in Dutch Batavia in 1870 - and followed the development of urban waters through the first two decades of Indonesian independence. As illustrated, the direct and indirect exclusion of much of Jakarta's kampong residents from access to piped water supply was articulated with both colonial and postcolonial practices of governance, which reinforced the spatial and social fragmentation of the city. In each period, the division of urban spaces, and the city's inhabitants into categories of modern and non-modern served specific political economic ends: the reaffirmation of Dutch sovereignty and racial superiority, as concretized in the provision of artesian, and later networked water supply solely to colonial neighbourhoods; the success of Sukarno's postcolonial 'guided democracy' as epitomized in water treatment plants serving as 'monumental architecture' connecting elite areas of the city.

Examining the urban water infrastructures of the colonial and postcolonial governments and the accompanying rationalizations and discourses that legitimated these interventions and prevented others, we have demonstrated how an ongoing fragmentation of Jakarta's water supply accompanied its concurrent (and current) centralization. We explain the operation of these seemingly contradictory processes as the product of both colonial and postcolonial attempts to differentiate people by class and by race, and to create a modern governable subject. We argue that the project of producing modernized, liberal, productive, ethical and obedient colonial citizens within a hygienic and economic urban environment entailed not only physical re-workings of urban space, but also discursive re-workings of the rationalities supporting water supply delivery; the associated classification of types of urban citizens was actively translated into differentiated urban spaces which persist in the contemporary city. This imbrication of water and constructions of citizenship is a persistent feature of the urbanization of water supply, and is still visible in the contemporary project of modernizing urban spaces and urban citizens according to neoliberal rationalities.

This genealogy reminds us that we should be wary of viewing cities such as Jakarta through a Northern lens, and provokes the need for alternative analytical frameworks acknowledging the city's (post)colonial construction. In Jakarta, fragmentation of utility services such as water is due not to the recent trends of 'splintering urbanism' characteristic of cities in the North, but is due rather to a model of urbanization with roots in the colonial era that has produced persistent patterns of differentiation of spaces, classes, and races. Using 
a postcolonial perspective to interrogate the contemporary urban geography of Jakarta is - like in other cities of the South (see Myers 2006) - necessary in order to unlock the crucial elements of colonial legacies. The contemporary lack of access is not simply due to neoliberal trends in urban governance. ${ }^{21}$ Rather, the roots of disconnection and disenfranchisement are structured within patterns of governance that have been materially inscribed in the city's infrastructure over the past century. This analysis underscores the limitations of conceptual frameworks predicated on an ideal-type of homogeneous and universal modern infrastructure networks, and reinforces calls for alternative theories of urbanization in the South.

\section{References}

Abeyasekere, Susan (1987). 'Death and disease in 19th century Batavia', in: N. Owen (ed.), Death and disease in Southeast Asia: Explorations in social, medical and demographic history, pp. 189-209. Singapore: Oxford University Press.

Abeyasekere, Susan (1989).Jakarta: A history. Singapore: Oxford University Press.

Argo, Teti (1999). Thirsty downstream: The provision of clean water in Jakarta, Indonesia. [PhD thesis, University of British Columbia, Vancouver.]

Azdan, M.D. (2001). Water policy reform in Jakarta, Indonesia: A CGE analysis. [PhD thesis, Ohio State University, Columbus.]

Bakker, Karen (2003). 'Archipelagos and networks: Urbanization and water privatization in the South', Geographical Journal 169(4):328-341.

Bakker, Karen et al. (2008). 'Governance failure: Rethinking the institutional dimensions of urban water supply to poor households', World Development 30:1891-1915.

Balbo, M. (1993). 'Urban planning and the fragmented city of developing countries', Third World Planning Review 15(3):23-35.

Blussé, L. (1985). 'An insane administration and an insanitary town: The Dutch East India Company and Batavia (1619-1799)', in: R. Ross and G. Telkamp (eds), Colonial cities, pp. 65-85. Dordrecht: Martinus Nijhoff.

Booth, Anne (1988). 'Living standards and the distribution of income in colonial Indonesia: A review of the evidence, Journal of Southeast Asian Studies $19(2): 310-334$.

Brandenburg, W.H. (1924). 'De watervoorziening van kleine Indische gemeenten', De Waterstaats-Ingenieur 6:149-169.

21 The involvement of the private sector in water supply, devolution of governance to lower orders of government, or deregulation of the water sector have all occurred in Indonesia over the past decade. 
Breen, H. van (1916). Beschouwingen:van de Technische- en Watervoorzieningscommissies betreffende de verschillende in zake de voorgenomen verbetering van de watervoorziening der Gemeente Batavia verschenen artikelen en uitgebrachte adviezen. Batavia: Ruygrok and Co. [Gemeenteraad van Batavia, Gedrukte Stukken No. 40.]

Cestti, R., R. Batia and C. van der Berg (1994). Water demand management and pollution control in the Jabotabek region, Indonesia. Jakarta: The World Bank.

Chifos, C. and H. Suselo (200o). 'Thirty years of urban infrastructure development in Indonesia, in: C. Chifos and R. Yabes (eds), Southeast Asian urban environments, pp. 153182. Temple: Arizona State University, Program for Southeast Asian Studies.

Cobban, James (1974). 'Uncontrolled urban settlement: The kampong question in Semarang (1905-1940)', Bijdragen tot de Taal-, Land- en Volkenkunde 130:403-427.

Cobban, James (1988). 'Kampungs and conflict in colonial Semarang', Journal of Southeast Asian Studies 19(2):266-291.

Coté, Joost (2003). 'A conglomeration of [...] often conflicting ideas: Resolving the 'Native Question' in Java and the Outer Islands in the Dutch East Indies, 1900-1925', Itinerario $3(4): 160-188$.

Cowherd, Robert (2002). Cultural construction ofJakarta:Design, planning and development in Jabotabek, 1980-1997. [PhD thesis, Massachusetts Institute of Technology, Boston.]

Doorne, J. van (1983). A divided society: Segmentation and mediation in late-colonial Indonesia. Rotterdam: Erasmus University, Comparative Asian Studies Program.

Drost, D. (1918). Ontwerp bronwaterleiding voor Batavia. Weltevreden: Albrecht and Co.

Eggink, E.J. (1930). 'Na 25 jaar': Beknopt gedenkschrift ter gelegenheid van het 25 jarig bestaan der gemeente Batavia. Batavia: Gemeente Batavia.

Fischer, L. (1959). The story of Indonesia. New York: Harper Brothers.

Foucault, Michel (1991). 'Governmentality', in: G. Burchell, C. Gordon and P. Miller (eds), The Foucault effect, pp. 87-104. London: Harvester Wheatsheaf.

Geertz, C. (1963). Old societies and new states: The quest for modernity in Asia and Africa. New York: Chicago University, Committee for the Study of New Nations, Free Press of Glencoe.

Gemeente Batavia (1937). Batavia als handels-, industrie-, en woonstad. Batavia and Amsterdam: Kolff.

Gomperts, S.J. (1916).'Waterverbruik door minvermogende inlanders en vreemde oosterlingen bij indische drinkwatervoorzieningen', De Waterstaats-Ingenieur 1:11-14.

Gouda, Frances (1995). Dutch culture overseas: Colonial practice in the Netherlands Indies 1900-1942. Amsterdam: Amsterdam University Press.

Graham, Stephen (2001). 'The spectre of the splintering metropolis', Cities 18(6):365-368.

Graham, Stephen (2002). 'On technology, infrastructure, and the contemporary urban condition: A response to Coutard', International Journal of Urban and Regional Research 26(1):175-182. 
Graham, Stephen and Simon Marvin (2001). Splintering urbanism. London: Routledge. Grant, B. (1964). Indonesia. Melbourne: Melbourne University Press.

Hamer, A., A. Steer and D. Williams (1986). Indonesia: The challenge of urbanization. Washington D.C.: The World Bank. [Staff Working Paper No. 787.]

Hamlin, C. (2000). "Waters" or "Water"? - Master narratives in water history and their implications for contemporary water policy', Water Policy 2:313-325.

Hanna, Willard A. (1959). Bung Karno's Indonesia: The impact of Djakarta. New York: American Universities Field Staff. [Southeast Asia Series VII (28).]

Jaarboek van Batavia (1927). Jaarboek van Batavia en Omstreken. Batavia: G. Kolff \& Co.

Jellinek, Lea (1991). The wheel of fortune: The history of a poor community in Jakarta. Honolulu: University of Hawaii Press.

JICA (1997). The study on the revise of Jakarta Water Supply Development Project, Final Report, Volume 2, Main Report. May 1997. Jakarta: Nihon Suido Consultants Co., Ltd and Nippon Koei Co., Ltd.

King, A. (1990). Urbanism, colonialism and the world economy. London: Routledge.

Kooy, Michelle (2008). Relations of power, networks of water: Governing urban waters, spaces, and populations in (post)colonial Jakarta. [PhD Thesis, University of British Columbia, Vancouver.]

Kroef, J. van der (1954). Indonesia in the modern world, Vol.1. Bandung: Masa Baru.

Kusno, Abidin (1997). 'Modern beacon and the traditional polity: Jakarta in the time of Sukarno', Journal of Southeast Asian Architecture 1:25-45.

Kusno, Abidin (2000). Behind the postcolonial: Architecture, urban space and political cultures in Indonesia. London and New York: Routledge.

Leclerc, Jacques (1993). 'Mirrors and the lighthouse: A search for meaning in the monuments and great works of Sukarno's Jakarta, 1960-65', in: Peter J.M. Nas (ed.), Urban symbolism, pp. 38-58. Leiden: E.J. Brill.

Leeuwen, C.A.E. van (1917). 'Het huidige vraagstuk der watervoorziening van Batavia en Mr.Cornelis: voordracht, gehouden in de openbare vergadering der afdeeling Batavia van 14 Februari 1917', De Waterstaats-Ingenieur 3:81-103.

Leeuwen, C.A.E. van (1920). 'Het rioleeringsvraagstuk in Nederlandsch-Indie', De Waterstaats-Ingenieur 5:196-212.

Li, Tania Murray (1999). 'Compromising power: Development, culture and rule in Indonesia', Cultural Anthropology 14(3):295-322.

Li, Tania Murray (2001). 'Relational histories and the production of difference on Sulawesi's upland frontier', Journal of Asian Studies 6o(1):41-66.

Locher-Scholten, Elsbeth (1997). 'Summer dresses and canned food: European women and Western lifestyles in the Indies, 1900-1942', in: Henk Schult Nordholt (ed.), Outward appearances: Dressing state \& society in Indonesia, pp. 151-180. Leiden: KITLV. 
MacDonald, G. (1995). 'Indonesia's Medan Merdeka: National identity and the built environment', Antipode 27(3):270-293.

Maronier, V.F.C. (1929). 'De drinkwatervoorziening van Batavia', De WaterstaatsIngenieur 8: 223-239.

McGranahan, G., et al. (2001). The citizens at risk: From urban sanitation to sustainable cities. London: Earthscan.

Melosi, M. (2000). The sanitary city: Urban infrastructure in America from colonial times to the present. Baltimore: Johns Hopkins University Press.

Milone, Pauline D. (1967). 'Indische culture, and its relationship to urban life', Comparative Studies in Society and History 9:407-426.

Moens, Bernelot J.C. (1873). 'Het drinkwater te Batavia: Geschiedenis van het drinkwater te Batavia, rapport omtrent een ingesteld onderzoek', Geneeskundig Tijdschrift voor Nederlandsch-Indie 15:275-488.

Mrázek, Rudolf (2002). Engineers of happy land: Technology and nationalism in a colony. Princeton and Oxford: Princeton University Press.

Myers, Garth (2006). 'The unauthorized city: Late colonial Lusaka and postcolonial geography', Singapore Journal of Tropical Geography 27: 289-308.

PAM Jaya (1992a). PAM Jaya 7o years, 1922-1992. Jakarta: PAM Jaya.

PAM Jaya (1992b). 'PAM DKI 1922-1992', in: PAM Jaya 7o years, (1992), pp. 13-29. Jakarta: PAM Jaya.

Porter, R. (1994). The economics of water and waste: A case study of Jakarta. Aldershot: Avebury.

Raay, J.F.A. van (1915). 'Watervoorziening van Batavia II', De Ingenieur 8:135-144.

Robison, Richard (1986). Indonesia: The rise of capital. Wellington: Allen \& Unwin.

Smitt, A. (1922). De waterleiding van Batavia. Batavia: Landsdrukkerij.

Stoler, Anne (1997). Race and the education of desire: Foucault's history of sexuality and the colonial order of things. Durham: Duke University Press.

Surjadi, C. et al. (1994). Household environmental problems in Jakarta. Stockholm: Stockholm Environment Institute and Jakarta: Urban Health Study Group of Atma Jaya University.

Taylor, Jean Gelman (1983). The social world of Batavia: European and Eurasian in Dutch Asia. Madison: University of Wisconsin Press.

Wertheim, W.F. (1956). Indonesian society in transition: A study of social change. The Hague: W. van Hoeve.

Wetering, F.H. van der (1939). 'Kampongverbetering', Koloniale Studien 4:307-325.

World Bank (1974). Appraisal of the Jakarta Urban Development Project in Indonesia. Jakarta: The World Bank. [Transportation and Urban Projects Department, Report No. 475a-IND, August 30 1974.]

wHo (World Health Organization) (2004). Facts and figures: Water, sanitation and hygiene links to health. Geneva: World Health Organization. 